\title{
The Evolution of Chagas Disease (American Trypanosomiasis) Control after 90 Years since Carlos Chagas Discovery
}

\author{
JCP Dias ${ }^{+}$, CJ Schofield* \\ Centro de Pesquisas René Rachou-Fiocruz, Caixa Postal 1743, 30190-002, Belo Horizonte, MG, Brazil \\ * Department of Infectious and Tropical Diseases, London School of Hygiene and Tropical Medicine, Coordina- \\ tor of the European Community \& Latin America Network on Biology and Control of Triatomines (ECLAT), \\ London WC1 E7TH, UK
}

Key words: Chagas disease - control - trypanosomiasis

\section{INTRODUCTION AND HISTORICAL ASPECTS}

Chagas disease is one of the most serious parasitic diseases of Latin America, with a social and economic impact far outweighing the combined effects of other parasitic diseases such as malaria, leishmaniasis and schistosomiasis. Serological data indicate well over 16 million people are infected with the causative agent, Trypanosoma cruzi, with a further 100 million people considered at risk (WHO 1991). The World Bank, in 1993, calculated an annual loss due to Chagas disease of 2,740,000 'disability-adjusted life years' (DALYs), representing an economic loss to the endemic countries of Latin America equivalent to over US\$6.5 billion per year (WHO 1997, Schofield \& Dias 1999).

Control of Chagas disease is now given high priority by Latin American governments, partly because of its high economic impact and consequent financial benefits of effective control (eg. Schofield \& Dias 1991, Akhavan 1996, Basombrio et al. 1998) but also because of the technical feasibility of control through the interruption of transmission. In 1991 a major regional initiative to eliminate Chagas disease was launched by the governments of Southern Cone countries (Argentina, Bolivia, Brazil, Chile, Paraguay, and Uruguay) (cf. Kingman 1991, Schofield \& Dias 1999), which has recently been followed by similar initiatives in Andean Pact countries (Colombia, Ecuador, Peru, and Venezuela) and Central America (El Salvador, Guatemala, Honduras, Nicaragua) (Schofield \& Dujardin 1997, WHO 1997).

E-mail: jcpdias@ netra.cpqrr.fiocruz.br Received 9 June 1999

Accepted 9 August 1999
Chagas disease can be transmitted by several mechanisms. Numerically however, vector-borne transmission is the most important, generally accounting for over $80 \%$ of all transmission of $T$. cruzi to humans. Direct observations, and mathematical models, indicate that social and political development of the endemic regions could be sufficient to control Chagas disease (and many associated problems). Yet this route is complex in the less developed regions, largely because it involves rural areas that traditionally receive little political priority (Caldas Jr 1980, Litvoc 1985, Dias 1987). But the epidemiological patterns of Chagas disease present a series of vulnerable points that can be attacked through national or regional control programmes. Regrettably, neither vaccines to prevent infection, nor drugs suitable for large-scale treatment, are currently available, but techniques for the interruption of transmission are now well established and are being progressively implemented throughout the endemic areas of Latin America.

Today, there is a general consensus that human Chagas disease will be overcome through interventions against different levels in the cycle of transmission (WHO 1991, Dias 1993a, b, Schofield 1994). At the primary level, interventions are designed to prevent transmission. At the secondary level, interventions are designed to prevent or inhibit disease in cases where infection has occurred, while at the tertiary level the interventions seek to limit human incapacity and reintegrate infected people into the community (Dias 1997). This paper presents a summarised overview of the control of Chagas disease, considering some historical aspects and the general context of the fight against the disease in endemic countries.

The discovery of Chagas disease constitutes one of the most exciting pages of the history of medical science. In parallel with the clinical, epidemiological, biological and pathological aspects that he studied, Carlos Chagas stated very early that, first 
of all, control of the disease represented a "duty for the State". In his admirable work, Chagas pointed out that control of transmission would be the most desirable goal and the best strategy in the fight against the disease which now bears his name. His comprehension about the problem was established in three basic points (Chagas 1911): (1) the epidemiological and social impact of the disease would be extremely relevant, considering the very large dispersion of the vector and the possibilities of high prevalence of human infection in Brazil and other countries of Latin America; (2) the basic focus on governmental programmes against the disease would be of preventive nature, since the cure of human $T$. cruzi infection had many technical problems and the control of transmission certainly would be the most vulnerable point to intervention in the epidemiological chain, and; (3) the fundamental point for intervention would involve vector control. Nevertheless, Chagas suspected that other mechanisms of transmission existed, for instance, congenital transmission.

Carlos Chagas very soon realised that political aspects might primarily be involved in disease control, since he perceived that human American trypanosomiasis (HAT) was basically a disease affecting extremely poor rural populations who were living in very bad housing conditions, such a situation providing an ideal condition to vector colonisation. Chagas stated that the main frame for the HAT undoubtedly would the house infested by triatomine bugs and clearly said in his famous II Conference (Chagas 1911):

"Cumpre salientar que o principal facto epidemiologico da moléstia é constituido por um insecto, companheiro constante do homem nos domicilios e, por isso mesmo, facilmente attingivel às medidas de destruição....Medidas sanitarias nesse sentido, visando, sobretudo, modificar as condições de habitabilidade .....importariam, sem dúvida, em acto administrativo do maior proveito".

("It is clear that the basic epidemiological fact of the disease is constituted by an insect, a constant companion of men in their houses, and thus easily vulnerable to destruction....Sanitary measures in this sense, especially improvement of the living conditions, would certainly represent an administrative act of major importance").

Chagas was an excellent malariologist, probably the most important in Brazil at that time. He was in charge of an anti-malaria campaign in Minas Gerais when he discovered the trypanosomiasis. Nevertheless, since his first works he stated very clearly what were the main differences in clinical and pathological aspects of these diseases, and also discussed possible strategies of control. Vaccination was not feasible for either disease, and spe- cific treatment would certainly present difficulties in trypanosomiasis. Because effective insecticides against triatomine bugs did not exist at that time (in contrast with malaria, for which mosquito larvicides were available and used by Chagas), his attention was directed to housing improvement. One of Chagas' disciples, HC Souza Araujo (1919), had an important influence, proposing in the state of Paraná (Brazil) a law making compulsory house improvement in endemic areas to prevent HAT. However, this law was never implemented during Chagas' life, and there were no government or regional efforts to break the disease transmission until the end of the 1940s (Chagas died in 1934). But Chagas was conscious of the difficulties of HAT control, in spite of his tremendous anxiety to face the disease in all possible ways. Very soon he perceived that political will never would come unless the disease and its social and economical impact were recognised. An entomological line of research at laboratory and field level was swiftly developed in "Manguinhos" and in several parts of the Americas, providing important information about vector and parasite distribution throughout the continent. But this line would not be sufficient, since the basic political subject was not the parasite, but human disease. At this point, Chagas worked in several projects seeking to clarify the epidemiology of HAT, particularly in relation to diagnosis and clinical characterisation of the chronic phase of the disease - especially chronic heart disease (Laranja 1949, Dias 1988). Nevertheless, during the first 30 years after the discovery, knowledge of the disease remained polarised between entomological aspects and the acute phase of HAT - reflecting the fashion for microbiological research of that time. Another constraint was the lack of interest of European and North American researchers to study a strictly Latin American pathology. At that time, Latin American countries were independent and their attractive mines of gold, silver and other precious minerals were rapidly becoming non-productive. European attention was focused on their colonies in Asia and Africa, where classical institutes for tropical medicine were installed. Carlos Chagas and Oswaldo Cruz were conscious of these facts, but still sought to interest the international scientific community in the new pathology discovered in Lassance. Chagas' works were therefore published in the USA, Europe and Argentina, written in English, French, German and Spanish. Important figures such as Hartmann, Prowazek, Metchnikoff, Brumpt, Crowell and Laveran were contacted, but Chagas reserved his greatest efforts to prepare his own group at the national level. In 1913 Chagas induced his assistants C Guerreiro and A Machado to apply the Bordet and Gengou 
technique to detect anti-T.cruzi antibodies in chronic patients. At the same time he began to develop his own research on chronic disease, latterly with the assistance of Eurico Villela and Evandro Chagas who chiefly focused on chronic cardiopathy. For them, it soon became clear that chronic heart disease was the most relevant aspect of all HAT (Dias 1988, Coura 1997). Once more Chagas was proved correct, but again he could not escape from another personal frustration: in spite of his magnificent descriptions, the clinical and pathologic aspects of chronic disease were not appreciated by the majority of scientists of his time. In parallel, serological diagnosis of chronic infection only became generalised in the 1940s following successful work carried out in Bambuí (E Dias \& cols) and in São Paulo (P Freitas \& cols); in the same way, chronic chagasic cardiopathy only became widely at the end of the 1940s, again following detailed studies by the Bambuí group (Laranja et al. 1956, Dias 1988, Coura 1997). Data collected by Laranja (1949) about the evolution of knowledge and the description of the chronic chagasic cardiopathy (CCC) can be summarised as follows: (a) until 1930, cases of CCC were only described in Lassance, by Chagas and Villela; (b) from 1930 to 1944, only 45 new CCC cases were described in Brazil, all from Lassance; (c) the first case of CCC described outside Brazil was published in Argentina, 1934, where 133 other cases were detected up to 1944; (d) in Brazil, between 1944 and 1948, another 600 cases of CCC were registered, mainly from Bambuí; (e) in contrast, from 1909 to 1948 , more than 2.000 acute cases were registered, the majority of them in Argentina, Brazil and Uruguay.

Chagas remained patient. In his last works and conferences, he still emphasised the chronic aspects of the disease, certainly waiting for confirmation of his findings elsewhere. In 1932 (published in 1934) he wrote:

"Firstly verified in Brazil, in the hinterland of Minas Gerais, this other human trypanosomiasis is not an exclusive disease of our country, since it was also recognised in other countries of South and Central America. In Argentine, in Tucuman and Catamarca provinces, several clinical cases were observed, with the verification of the parasite in their peripheral blood, as well as in Peru, Venezuela, San Salvador and, recently, in Panamá. But we still have little knowledge concerning the endemic index and the social importance of the disease in these other American countries..." (Chagas 1934).

At the same time, in spite of the sad episode of the National Academy of Medicine (where medio- cre and jealous enemies aggressively questioned Chagas) he never lost his hope in the force of science to control diseases and to improve health for the people:

"The European nations, zealous of their colonies in the tropics, have organised the expertise in their universities and in their great research institutes - to the study and the teaching of pathology in tropical countries. Here, not so much the economic interests, but the most exalted duties and provident nationalism oblige us to study and to research the Brazilian nosology, in order to provide the improvement of our race, of rare native attributes, and to reach, by the prophylactic method, the sanitary redemption of our large territory" (Chagas 1926).

\section{THE MODERN ERA OF CHAGAS DISEASE CON- TROL}

\section{Vector control}

In the 1930s, an increasing number of acute cases were being detected in Argentina by Mazza, Romaña, etc., and in Uruguay (by Talice \& Rial) following important work by MEPRA in Argentina - particularly the description of Romaña's sign as a diagnostic indication of acute infection. There were attempts at prevention, chiefly by Talice and Mazza, focusing again the question of housing improvement. But systematic control efforts only began to develop when a small branch of the Oswaldo Cruz Institute was set in Bambuí, Minas Gerais, where dozens of acute cases were detected by Vianna Martins (a general parasitologist) and subsequently by Emmanuel Dias (one of Chagas' disciples), in the beginning of the 1940's. This "Centro de Estudos e Profilaxia da Moléstia de Chagas do Instituto Oswaldo Cruz " represents the first institutional effort to promote Chagas disease control. It was promoted through the influence of Evandro Chagas and Amilcar Vianna Martins and implemented by Emmanuel Dias, under the decision of the Institute Director, Dr Henrique Aragão. In 1943/44, Dias made a complete survey of the municipality, finding astonishing epidemiological indicators such as a house infestation rate of $70 \%$, natural infection of the bugs by T.cruzi around 30$40 \%$, and $45 \%$ of positive serology among rural children under 10 years old (Dias 1944, 1997). Two basic research lines were established between 1943 and 1961: (a) control of transmission, focused mainly on vector control, and, (b) the study and clinical characterisation of chronic heart disease. The first line was immediately started by means of physical and chemical control of domestic vectors, including house improvement and intensive health education. The second line demanded development of a complex research structure, involving cardi- 
ologists (mainly Dr Francisco Laranja), general doctors (Dr Genard Nóbrega), serologists (particularly Dr Julio Muniz) and pathologists (Drs Magarinos Torres and A Miranda), all leaded by Emmanuel Dias. The first clinical studies were performed between 1945 and 1956, resulting in several publications about acute and chronic Chagas disease, focused particularly on cardiac pathology. The group also looked for experimental models, succeeding in reproducing all aspects of the human disease in dogs and monkeys (Laranja 1949, Dias 1993-c). In 1956 the group published their conclusions about Chagas cardiopathy in Circulation (the most important medical journal on cardiology, at that time), a work which is still considered as the definitive contribution about the characteristics of chronic Chagas heart disease (Laranja et al. 1956). In relation to disease prevention, Dias easily reached the conclusion that the transmission of $T$. cruzi to man was directly dependent on infected vector populations in human dwellings, realising the correlation between incidence and prevalence of human disease and the level of infested houses (Dias 1944, Hayes \& Schofield 1990). In his early attempts, Dias tried everything he could imagine to kill or remove triatomines from human dwellings. His early approaches included throwing boiling water, caustic soda, or kerosene, over the walls of infested houses, and even limited attempts using military flame throwers. At that time, the best results were obtained employing a mixture of rotenone and kerosene ( $\mathrm{C} 23 \mathrm{H} 22 \mathrm{O} 6)$, by which an enormous knock down effect was obtained against domestic Triatoma infestans and Panstrongylus megistus infestation. This gave an immediate reduction in the number of acute cases, especially when houses were also submitted to physical improvement (Dias 1944). Several other approaches have been tried but with the development of synthetic insecticides in the 1940s, chemical methods of vector control have become the most widely used technique, backed by low-cost systems of house improvement and community health education. DDT was found ineffective against most species of Triatominae (although it does have a latent effect against some species) but good results were obtained in early trials with another organochlorine, gamma-BHC (also known as $\mathrm{HCH}$, Lindane or Gammexane) (Dias \& Pellegrino 1948, Romaña \& Abalos 1948). BHC (and/or dieldrin) remained the most widely used compound against domestic Triatominae until the late 1970s when it was progressively replaced with synthetic pyrethroids (Schofield 1994, Dias 1997).

By the end of the 1940s all the main tools and strategies for the control of domestic Triatominae were available, at least at the experimental or theoretical level. E Dias recruited to his group a brilliant medicine student, José Pellegrino, who helped him very much in the work. Other research groups were also developing work on the control of Triatominae, chiefly in Brazil [Freitas (1963) in S. Paulo, Szumlewiecs (1953), in Rio] and in Argentina (Romaña \& Abalos 1948). Nevertheless, large-scale control programmes could not start until the beginning of the 1960s, because of the lack of political decision and the absence of national structures capable of implementing control programmes. For these reasons, Emmanuel Dias put his best efforts to stimulate the national director of the Brazilian Endemic Diseases Programme (DNERu), Dr Mário Pinotti, to launch a regional control trial in Uberaba in the State of Minas Gerais during 19511952. The results were excellent, and stimulated other regional initiatives during the 1960s such as the São Paulo State Programme (by Freitas, Rocha e Silva \& others) and large scale trials carried out in Argentine (by Cichero, Soler and Abalos), in Chile (by Neghme \& Schenone) and in Venezuela (by Pifano \& Gabaldón) (Dias 1993-b, 1988). National programmes followed, all based on chemical control methods against domestic Triatominae and using the rationale and strategies of the successful malaria campaigns. In Venezuela, as well as insecticide application, a national programme to improve rural dwellings was implemented, capitalising on the strong economy and public health expertise of the country at that time (Dias 1988). Through the 60 s and 70 s, a series of different control approaches were tested (Table 1) but insecticides remained the most effective and efficient approach (Dias 1957, 1994, 1997, Rabinovich et al. 1979, Rocha e Silva 1979, WHO 1991).

The introduction of synthetic pyrethroids in the early 80 s was a major advance in campaigns to control domestic Triatominae. All those currently used are alpha-cyano-substituted pyrethroids, applied as wettable powder (WP) or suspension concentrate (flowable) (SC) formulations using constant pressure backpack sprayers, generally of 8 or 101 capacity. These pyrethroids are fast acting against the target Triatominae, and also provide transient control of other domestic insect pests such as fleas, cockroaches and houseflies. They are considerably more expensive per $\mathrm{kg}$ than the previously used organochlorine insecticides, but are applied at much lower doses (Table II). Comparative studies show them to be considerably more cost effective (eg. Oliveira Filho 1989, Schofield 1994) and they have the additional advantages of greater acceptability to householders (being odourless and leaving no stains on the walls after application) and safety (2500 times less toxic to 
TABLE I

Methods of control tested against domestic Triatominae

Conventional insecticides

Insect growth regulators

Insect pathogens (eg. nematodes, fungi)

Other biological control (eg. egg parasitoids)

Genetic control (eg. liberation of sterile or substerile males)

Traps (eg. baited with lights, kairomones)

Housing improvement (eg. wall plaster, replacement of thatch roofs)

Health education (eg. improve public awareness, support of vigilance programmes)
Organochlorine compounds (eg. BHC \& Dieldrin), organophosphates (eg, malathion, fenitrothion), carbamates (eg. propoxur) and modern pyrethroids (see Table II); advantages: cheap, effective, available, safe for mammals; disadvantages: loss of residual activity on porous mud walls and peridomestic habitats

Eg: juvenile hormone mimics, precocenes; advantages: highly specific; safe for mammals; disadvantages: slow acting, active against only a few stages

Advantages: safe for mammals; disadvantages: greatly limited by climatic factors, difficult application

Advantages: safe for mammals; disadvantages: expensive, ineffective.

Advantages: none; disadvantages: expensive, unethical to releas e potential vectors

Advantages: none; disadvantages: ineffective

Advantages: effective; general improvement of living standards; disadvantages: difficult to implement on a large scale; tends to be costly

Advantages: general improvement of education and living standards; disadvantages: great expectations are not always fulfilled mammals than organochlorines). They are also well accepted by spraymen, although they occasionally produce transient irritation of the eyes and mucosa during application. Other formulations of conventional insecticides have been tried against triatomines, chiefly looking for a more consistent residual effect. These include microencapsulated formulations of pyrethroids, and slow release PVC matrices containing organochlorine or organophosphate (malathion) compounds. These formulations tend to have more residual activity, but their final cost-effectiveness is usually no better than conventional pyrethroids. Other approaches using ionised micro drops of active ingredient (Electrodyne) and/or spatial ultra-low volume spraying showed no advantages when compared with classical spraying methods. Synergists such as PBO (Piperonyl butoxide) seem not improve the action of pyrethroids against Triatominae (Dias 1997).

Among all triatomine species, undoubtedly the most important has been T. infestans, responsible for the majority of cases of Chagas disease in the Continent. It is present in the six countries of Southern Cone, and in southern Peru, and is almost entirely domestic throughout its wide distribution. The spread of $T$. infestans to its current wide distribution appears to have been relatively recent, associated mainly with human migration patterns (Schofield 1988). Since Emmanuel Dias and Alina Szumlewics, in the 40s and 50s, the behavioural biology and population dynamics of this species have been intensively studied, and several comprehensive reviews have been published. First of all, the species became almost completely domiciliated in all its area of dispersion, with the exception of some restricted rural areas of Bolivia

\section{TABLE II}

Types of pyrethroid insecticide and recommended dose of active ingredient to be applied for the elimination of domestic Triatominae

\begin{tabular}{lccc}
\hline & Formulation & Dose rate $(\mathrm{mg}$ a.i./sq, m) & Manufacturer \\
\hline Deltamethrin & $2.5 \% \mathrm{SC}$ (or 5\% WP) & 25 & AgrEvo \\
Cyfluthrin & $10 \% \mathrm{WP}$ & 50 & Bayer \\
Beta-cyfluthrin & $12.5 \% \mathrm{WP}$ or SC & 25 & Bayer \\
Cypermethrin & $20-40 \% \mathrm{WP}$ & 125 & Various \\
Lambda-cyhalothrin & $10 \% \mathrm{WP}$ & 30 & Zeneca \\
\hline
\end{tabular}

SC: suspension concentrate (flowable); WP: wettable powder. 
where it can be found in sylvatic ecotopes (Schofield 1994, Dias \& Coura 1997). Of particular interest in relation to vector control interventions is the insect's relatively slow rate of population regeneration and the susceptibility of nymphs and adult bugs to modern insecticides. In addition, the bugs have a very specialised genetic system with holocentric chromosomes and extremely low rates of genetic variability. The practical consequences of these facts in vector control correspond to the extreme difficulty these insects have in selecting insecticide resistance. In summary, $T$. infestans has at least four biological characteristics functioning as key factors favouring its control: (a) limited range of habitats, with all stages confined to houses and some peridomestic animal enclosures; (b) slow rate of population development, and consequent low rate of genetic rearrangement; (c) extreme specialisation with a low rate of genetic variability and consequently limited genetic repertoire for further adaptation (including insecticide resistance), and, (d) complete susceptibility to modern pyrethroid insecticides (Schofield \& Dias 1998).

Organisation of control campaigns against Triatominae is generally based on the administrative structures previously set up for campaigns against other insect pests - particularly mosquito vectors of yellow fever and malaria. And the operational procedure is also similar, with three main phases of intervention: preparatory, attack, and vigilance. The preparatory phase mainly involves arrangement of material and financial resources, recruitment and training of personnel, and sketchmapping of the area to be treated - including, where possible, baseline serological studies of the population to determine initial infection rates. The attack phase generally involves large-scale spraying of all premises in the target area, regardless of whether or not an individual house is known to be infested. This is because available sampling methods are imprecise, and may not detect low-density triatomine populations (Schofield 1978, Gurtler et al. 1993). Householders are advised to remove all foodstuffs and animals, and asked to pull furniture away from the walls. All internal and external wall surfaces are sprayed, together with the inside roof surface and all peridomestic animal enclosures. Following the attack phase, dwellings must be evaluated for the presence of Triatominae by teams of trained personnel using torch and forceps to examine cracks and crevices in the house. Sometimes sheets of paper (Garcia Zapata et al. 1985) or special cardboard boxes (Gómez-Nuñez 1965) are placed on the walls as passive sampling devices; subsequent deposits of bug faeces on the papers will indicate the presence of triatomine bugs.
If the post-spray evaluation indicates more than $5 \%$ of the houses still appear to be infested with Triatominae, then the area is programmed for a repeat application as in the original attack phase. If less than $5 \%$ of houses appear to be infested, then the area is placed under vigilance, whereby any premises still infested can be selectively retreated. The decision level at 5\% house infestation rate has been determined on the basis of experience indicating that below this level new cases of T.cruzi infection are rare (Dias 1987).

The vigilance phase depends crucially on the participation of the local community, and is prepared from the start of the campaign through community health education and discussion with local community officials. The idea is that all householders are made aware of the objectives and rationale of the campaign, and can appreciate their important role in its success. In this way they can assist the spraymen during the attack phase, and then act as the 'eyes' of the control services during the subsequent vigilance, reporting the presence of triatomine bugs to the local information post, so that the house can be rechecked and resprayed if necessary.

Following this general schedule, the results have been very satisfactory in Brazil, Uruguay, Chile, and in large regions of Argentina, Venezuela, and parts of Bolivia and Paraguay. Where vector control has been satisfactorily implemented in these countries, acute cases of Chagas disease are no longer seen, and serology of young children (born since the launch of the control campaigns) shows very low rates of infection (Dias 1993a, Schmunis et al. 1996, WHO 1997). In addition, the prevalence of $T$. cruzi infection is also decreasing amongst blood donors and women of child-bearing age, bringing corresponding reductions in the risk of transfusional and congenital transmission (Dias 1997). Table III, from the official reports of Southern Cone Initiative, shows the reduction of seropositivity over the last few years (WHO 1997, Schofield \& Dias 1999).

Consolidation of successful vector control interventions depends on two important concepts, applicable to different epidemiological situations. The objective is to ensure that treated premises remain free of triatomine bug infestations. Continual retreatment with insecticides, as has been carried out in the past against endophilic mosquitoes, is neither practical nor desirable, especially given the slow rate of recolonisation of houses by most triatomine species. Instead, the strategy is to inhibit reinfestations by: (a) eliminating all residual foci of infestation that could give rise to new bug colonies, and (b) progressive socio-economic development and house improvement to render 
TABLE III

Seroprevalence (in \%) of Trypanosoma cruzi infection in five Southern Cone countries from large scale surveys before and after initiation of the Southern Cone Programme (Schofield \& Dias 1999) ${ }^{a}$

\begin{tabular}{lccl}
\hline Country & $1981-1985$ & $1993-1995$ & Observations \\
\hline Argentina & 4.8 & 1.2 & 18 year-old military recruits \\
Brazil & $4,5(\mathrm{a})$ & $0.2(\mathrm{~b})$ & (a): general population; (b): 7-14 years old \\
Chile & 5.4 & 1.4 & $<10$ years old \\
Paraguay & 9.2 & 4.0 & 18 year-old military recruits \\
Uruguay & 2.4 & 0.2 & $<12$ years old \\
\hline
\end{tabular}

$a$ : values are percentage seropositive in the age groups shown.

houses less amenable to bug infestations, although for both scenarios the importance of communitybased vigilance cannot be stressed too highly. In the case of highly domestic species of Triatominae, such as T. infestans in Southern Cone countries, new infestations arise primarily through passive transport of bugs in the clothes and belongings of people travelling from infested to non-infested dwellings (Schofield 1988, Schofield \& Dias 1998). Consequently, the broad international strategy (PAHO 1993, Schmunis et al. 1996) is to eliminate all domestic foci of $T$. infestans throughout the region in order to eliminate the possibility of passive transport of bugs from one region to another. In the case of species that retain silvatic ecotopes however, complete elimination is impossible, so that greater emphasis is placed on adequate surveillance, selective retreatment of new infestations, and progressive improvement of rural housing (Schofield et al. 1990, Briceño-León 1993).

The new scenery of Chagas disease control programmes is replacing the classical vertical by the horizontal approach, since most of the countries are turning their Public Health systems to the decentralised model. In the years 90 , globalisation and market controlled economies imposed the general tendency to deliver resources and responsibilities to peripheral levels, in order to improve small and efficient central and national structures. In matter of fact, considering the general conditions of the regions where Chagas disease exists, the transition to decentralisation can be considered another new challenge, since the very poor municipalities and counties generally do not have sufficient expertise, organisation and political will to carry on the programme. Technically, at the present time no major problems exist concerning the fight against triatomines indoors: all the results can be considered very optimistic in those areas or regions where the programmes are being conducted with a minimum of quality, coverage and continuity (WHO 1991, Schofield \& Dias 1998). Nevertheless four other challenges emerge for the new century: (a) to maintain political decision (and natu- rally the necessary resources) in those regions where the disease impact fallen down; (b) to face objectively the irreversible tendency to centralization. In other words, to maintain minimum central and regional reference structures in order to improve the efficacy and continuity of finalistic activities at the peripheral level; (c) to control secondary and ubiquitous species at the peri-domestic level, and, (d) to maintain a high and permanent degree of community participation in order to improve a continuous epidemiological surveillance (Dias 1987, 1991, Schofield \& Dias 1999).

\section{Control of transfusional transmission}

Blood transfusion transmitting T. cruzi was one of the few subjects not suspected by Carlos Chagas, but discovered at the end of the 40's, after the advertising of Salvador Mazza, Emmanuel Dias and other pioneers. Transfusion is considered the second most important mechanism of transmission of Chagas disease to which currently accounts for around $15 \%$ of all transmission. The required methods for control of transfusional transmission have been available since the 1950 s, but have only been adopted on a large scale since the emergence of the Aids pandemic in the 1980s. As HIV can also be transmitted by blood transfusion - along with other pathogens such as hepatitis and syphilis - there is now greater emphasis on improving the quality of blood for transfusion to eliminate the risk of these infections.

There are three basic strategies according to the epidemiological situation (Wendel et al. 1992). In regions with high seroprevalence of $T$. cruzi infection amongst blood donors (20\% or more) or where serological screening systems are unavailable or unreliable, the best approach is to add gentian violet to stored blood $(1: 4000)$ for $24 \mathrm{hr}$ in order to kill any flagellates. This method has been very widely used for many years, and the blue colouration imparted to the transfused blood generally disappears a few days after transfusion. In areas with lower seroprevalence of $T$. cruzi infection the recommended approach is to screen all potential blood donors using at least two serologi- 
cal tests (usually Indirect Haemaglutination and Indirect Fluorescent Antibody tests); at the same time the blood can also be screened for HIV, hepatitis and syphilis (Dias 1978, Schmunis 1991, WHO 1991). The third approach, used in non-endemic areas such as the USA, is based on a preliminary questionnaire to see if the donor has any history of possible contact with $T$. cruzi or infected Triatominae (eg. has previously lived in an endemic region), which may then be followed by appropriate serological testing.

For endemic Latin American countries, the screening methods need to be complemented by adequate legislation obliging a standardised system of screening in all blood banks, and entirely prohibiting the use of paid blood donors. There is a corresponding need to promote correct clinical indications for the use of transfused blood and haemoderivates, the correct and immediate notification of transfusion accidents, and to stimulate modern practices such as auto-haemotransfusion (Wendel et al. 1992, Dias 1997). The research need is to improve serological screening techniques to achieve greater sensitivity and specificity at reduced cost, and to develop a serological 'gold standard' for all reference laboratories. Improved chemoprophylaxis for stored blood would also be helpful, because of the potential toxicity of Gentian Violet and its slow rate of action (Moraes de Souza et al. 1997).

Additionally, it is worth emphasising the integrated approach to Chagas disease control, in the sense that throughout the Americas blood banks are now one of the most important sources of epidemiological information on the seroprevalence of infection. Data from blood banks provide a useful baseline against which to judge the progress of Chagas disease control programmes, offering an important index of the changes in seroprevalence as control programmes proceed. Serological screening prior to blood donation also offers an important opportunity to identify infected individuals, who must be advised never to offer blood again and must be referred for clinical follow up, counselling, and supportive treatment where required (Dias 1997, Moraes de Souza et al. 1997, Dias \& Schofield 1998).

\section{Control of congenital transmission}

Congenital transmission of T. cruzi, although numerically small, is the third most important mechanism of transmission. Up to $4 \%$ of births from infected mothers can result in infected babies due to parasites crossing the placenta (Schmunis 1991, Dias \& Coura 1997) suggesting that up to 5000 new infections per year may be due to this route of transmission.
Unfortunately, congenital transmission cannot be prevented during pregnancy because available drugs are toxic and teratogenic, and preventive abortion is unacceptable. There is also no reliable way to detect intrauterine infections, so that the best procedure consists of early diagnosis of the new-born followed by specific treatment with benznidazole $(8-10 \mathrm{mg} / \mathrm{kg} /$ day during 60 days). Serology can be carried out on pregnant women with appropriate epidemiological history (eg. coming from an endemic area), thus detecting those at risk. However, conventional serology is not diagnostic for new-bornes because the baby will remain seropositive for 4-5 months due to passive transference of $\mathrm{IgG}$ antibodies from the infected mother. Instead, parasites can be sought directly or by haemoculture or indirect xenodiagnosis from the new-bornes, especially in those who present continuous fever or other suggestive symptoms such as myocarditis or hepato and splenomegaly. In countries such as Brazil where congenital cases are becoming rarer, the usual strategy is to use conventional serology when the babies reach 6 months (when maternal antibodies will have disappeared) and immediately treat those who result positive (Dias 1987, WHO 1991).

\section{Control of transmission by organ transplant}

Theoretically, transmission of T. cruzi can occur by the transplant of virtually any organ from infected donor to susceptible recipient. However, most cases have been recorded as a result of kidney transplantation, with rare cases attributed to transplants of heart, pancreas, and bone marrow. Pre-surgery serology of both donor and recipient should be obligatory in endemic areas, or when either has an epidemiological history of possible contact with the parasite. Nevertheless, in urgent cases the transplant must proceed and the best strategy is specific treatment of the infected donor (benznidazole $5-7 \mathrm{mg} / \mathrm{kg} / \mathrm{day}$ ) during the 10 days preceding surgery, and similar treatment of the recipient on the day before surgery and for 9 days afterwards. The rationale is to minimise circulating parasites in the donor in order to inhibit their establishment $\mathrm{n}$ the recipient (Dias et al. 1986). In cases where pre-surgical treatment of an infected donor is not possible, the recipient should be treated immediately after surgery. This applies also to cases of transplant from an uninfected donor to an infected recipient, since reactivation of acute Chagas disease can result from the use of immunosuppressants during transplant surgery (Ferreira et al. 1997).

\section{Accidental transmission}

Accidental transmission of $T$. cruzi is regrettably frequent in laboratories, and well over 50 cases 
have been recorded, generally as a result of accidental puncture from infected needles or splashing with contaminated triatomine faeces or culture material (Brener 1987). This problem must be addressed by very clear training of personnel and rigorous attention to good laboratory procedures. Laboratories should have a restricted entrance, and the use of gloves, protective eye-glasses, masks, closed shoes and long-sleeved gowns, should be obligatory for technicians working with the parasite. Periodic serological checks of laboratory staff are also advisable. Immediate local sterilisation must be provided after accidental contact with suspect material, and silver nitrate eye washes are indicated if the eyes were contaminated. If a person seems likely to have been infected, then an immediate presumptive course of treatment should be given, using benznidazole $(5-7 \mathrm{mg} / \mathrm{kg} / \mathrm{day})$ for at least 10 days.

\section{Vaccination and chemoprophylaxis}

Several forms of immunisation have been tested against $T$. cruzi, using attenuated strains, fractionated parasites, antigenically similar trypanosomatids, and synthetic molecules. None has been effective. 'Live' vaccines could not assure safety, while 'killed' vaccines could not provide total protection, and further research aimed at producing a vaccine against $T$. cruzi is no longer encouraged (WHO 1991). Similarly there is no drug that can be used for effective prophylaxis, for example to protect travellers who visit endemic areas. In this context however, it is worth emphasising that the risk of infection to travellers is extremely low.

\section{Reactivation of human Chagas disease}

As mentioned for organ transplanted individuals, some other situations involving immunological depression can re-activate $T$. cruzi infection. The most common situation concerns to HIV superinfection in chagasic patients, chiefly when the level of CD4 cells is lower than 300, generally resulting in severe neurological pictures. More than 40 cases are known, most of them with fatal evolution. Adequate treatment with anti retroviral drugs are able to prevent reactivation in these cases. Recently, it was also suggested to treat them with benznidazole $(5 \mathrm{mg} / \mathrm{k} /$ day three times weekly) in order to maintain a small number of circulating parasites (Ferreira et al. 1997).

\section{Treatment of infection}

Although the primary emphasis in Chagas disease control concerns the interruption of transmission, there remains a need to treat people who are already infected. This applies not only to specific cases such as transfusion and transplant surgery, congenital transmission and accidents as described above, but also to those infected in rural settings prior to the implementation of large-scale vector control interventions. Even if all transmission were immediately halted, there would remain some 16 million people requiring clinical attention over the next 30 years or so. In the context of the overall Chagas disease control strategy, treatment of infected individuals can be considered the secondary level of intervention, designed primarily to halt the progression of disease.

Specific treatment - There are two drugs that can be used for specific treatment of T. cruzi infection. Nifurtimox manufactured by Bayer under the trade name Lampit ${ }^{\circledR}$ is given at $10-15 \mathrm{mg} / \mathrm{kg}$ body weight per day, while benznidazole, manufactured by Roche under the trade names Radanil ${ }^{\circ}$, Rochagan ${ }^{\circledR}$ or Ragonil ${ }^{\circledR}$, is given at $5-7 \mathrm{mg} / \mathrm{kg}$ body weight per day. Treatment with either drug is indicated in acute or recent infections, and in congenital cases, with a good chance of radical cure. Acute infections are generally treated for up to 60 days, but Brazilian experience indicates that recent non-acute infections can be successfully treated with a 10 day regime, provided that treatment is started very soon after the initial infection. Abbreviated treatment regimes have the advantage of reduced likelihood of side effects, which generally commence after 8-10 days of treatment. Side effects are dosage dependent, and include malaise, anorexia, loss of appetite and of concentration, erythema, pruritus, and peripheral neuritis. In some cases, agranulocytosis and/or anaemia has been observed, requiring interruption of treatment. In general, children tolerate treatment much better than adults.

Use of nifurtimox or benznidazole has given variable results in different countries, which may reflect parasite strain differences. In general however, complete cure can be expected with immediate treatment of accidental infections, and 30-70\% cure for treatment of acute infections. Even if radical cure is not achieved, there is now strong evidence that early treatment can prevent mortality during the acute phase of infection, and can reduce the progression of disease in the subsequent chronic phase - especially in relation to cardiac lesions. Viotti et al. (1997) present results of a 10 year follow-up of treated and non-treated individuals in the chronic phase of infection, showing significantly improved clinical evolution in the treated group, as well as reduced mortality. At the experimental side, since the 70's, important trials made by Rowheder, Andrade (1999) and others have shown that both drugs were effective at the tissue level and that inflammatory response (and even initial fibrosis) is reversible when the parasite is killed throughout treatment. Specific treatment 
of chronic infections should therefore be considered on a case-by-case basis, bearing in mind the age of the patient since treatment is better tolerated in younger individuals, and the age of infection since greatest success is likely from more recent infections (WHO 1991). The modern tendency, nevertheless, is to give to the patient the "benefit of the doubt" treating specifically the cases of indeterminate and initial cardiac and digestive chronic forms (Dias 1997).

Symptomatic treatment - Symptomatic or supportive treatment for chronic phase patients has advanced greatly in recent years. Effective treatment presupposes adequate access to medical attention, with periodic clinical checks. Patients with indeterminate (asymptomatic) chronic infections need a yearly check, whereas those with severe arrhythmia or heart failure will require hospitalisation and weekly or monthly clinical examinations. In general, about $85 \%$ of chronic phase patients can be followed through the primary health care system, with periodic medical consultations, serology and electrocardiograms (Dias 1990). Management of the principal clinical manifestations can be summarised as follows:

Chronic cardiopathy: arrhythmias must be controlled by adequate diagnosis and treatment - usually with amiodarone and other modern antiarrhytmic drugs such as propaphenone and mexilethine. Severe arrhythmias may require pacemaker implant or other surgery. Cardiac surgery in Chagas disease has being improved with the resection of aneurysms and of myocardium zones where arrhytmogenic foci are detected. Prevention of heart failure is extremely important, and requires detection before the onset of cardiac enlargement. In chronic Chagas disease, the final phases of heart failure predict thrombi-embolic and refractory situations based on severe weakness of the cardiac muscles and advanced cardiac fibrosis. In such cases, the only possible recourse may be to heart transplantation.

Chronic digestive tract involvement: although intestinal megasyndromes are well recognised in many cases of advanced chronic infection, treatment should be conservative in the early stages. At the oesophagus level, the Heller technique (extra-mucosa miotomy) followed by plastic reconstruction of the sphincter is considered the most recommendable procedure for the cases up to 3rd degree, not only correcting disphagia and other current symptoms, but also preventing the evolution of megaoesophagus in a large number of cases. More aggressive surgical procedures are indicated mainly for the most advanced cases with severe dilatation and ectasy. The worst manifestation of megacolon, sygmoid volvulus, must be prevented or immediately corrected, although it is regrettable that the mortality rate from megacolon surgery remains high, in spite of modern techniques.

\section{Reintegration of chagasic patients into the com- munity}

This is the last stage in the classical sequence of preventive medicine. Often, a patient will panic or become severely depressed when a positive diagnosis is revealed, even in the absence of clinical manifestations. The public image of Chagas disease is commonly associated with sudden death and/or irreversible heart disease, an association that has been progressively incorporated due to inappropriate and sensationalist reporting of a minority of severe cases. Nevertheless, a person with positive serology must be informed of this result in order to avoid giving blood and to accept medical attention. Clinicians and health workers must give a realistic and non-sensationalist explanation of Chagas disease, pointing out its natural history and principal modes of transmission, as well as a balanced view of the patient's clinical prognosis. Facing the chagasic individual, the role of the clinician is to analyse carefully the case and discuss objectively the particular situation with the patient and family. Most cases do not represent serious clinical problems, and have little likelihood of serious manifestations in the short and medium terms. Moreover, available medical resources are continuously improving in terms of disease management, provided the patient is aware of the need for regular medical consultation and checks. A rarely discussed problem is the psychological behaviour of chagasic individuals, since most will suffer parasympathetic denervation, becoming hyper-reactive to common ambient stimuli - they become permanently stressed according Vieira (in Dias 1990). At the operational level, a present tendency is to allocate psychological attention in those medical services where chagasic people are attended (e.g. in Recife, São Paulo, Belo Horizonte, Goiânia and Campinas (Brazil) and in Cordoba (Argentina).

At the community level also, correct and balanced information must be given, especially to emphasise that Chagas disease is not contagious, and that the prognosis for infected individuals is generally good. This is particularly important in terms of the basic rights of the chagasic individual, the right to work (which is often refused to individuals merely because they present positive serology), and the right to social security (which is sometimes denied in cases of advanced heart disease). These aspects require well-prepared clinicians and health workers, clear practical guidelines, and an effective social security system. In practice, the basic problem is to define the perspec- 
tives and conditions for chagasic individuals, taking into account their clinical state, their profession and general living conditions. Each case must be carefully evaluated, avoiding distress to the patient but equally avoiding false expectations. At present, millions of chagasic individuals from rural areas of Latin America are migrating into cities, seeking work and better social conditions. Most remain in the chronic indeterminate phase of infection, or in the initial stages of chronic heart or digestive tract damage, and are physically quite capable of carrying out the majority of professions. On the other hand, some are in advanced stage of chronic impairment, requiring medical attention and a reduction in their physical labour in order to reduce the risk of cardiac failure or sudden death. But since many of the people infected with $T$.cruzi are illiterate or poorly educated, it remains the responsibility of the social security system and the medical profession to provide the best conditions for their survival and development (Dias 1997).

\section{SUMMARY OF THE PRINCIPAL EVENTS RELATED TO HUMAN CHAGAS DISEASE CONTROL FROM 1909 TO 1999}

In order to have a general and chronologic comprehension of the facts appointed above, the following picture was prepared, showing the considered most relevant facts concerning to the control of human Chagas disease, since its discovery and according to the consensus of the majority of the authors (Dias 1988, Coura 1997, Schofield \& Dias 1999):

\section{YEARS SUBJECT/OBSERVATION}

1909 Carlos Chagas discovers the disease

1911 Chagas proposes vector control and housing improvement and describes the congenital transmission of Trypanonoma cruzi

1913 Brumpt describes xenodiagnosis; Guerreiro and Machado develop complement fixation test

1916 Chagas emphasizes chronic heart disease 1918 Souza Araújo promotes a law concerning house improvement in endemic areas

1919-22 N Larrier and S Campos study congenital transmission at experimental level

1926 Mazza begins the MEPRA project in Jujuy, Argentina

1930-34 C Chagas and E Chagas employ EKG in chronic Chagas heart disease

1932-36 Mazza claims for housing improvement and tries some classical drugs in Chagas disease

1935 IX MEPRA meeting; Romaña describes his eye portal of entry sign

1935-44 Many acute cases are described in Ar- gentina, Brazil, Uruguay and Venezuela. Mazza warns about the risk of transfusion and oral (mother milk) transmission

1943 Foundation of the Bambuí center in Minas Gerais, Brazil, by Emmanuel Dias, where trials are made of several available insecticides (including cyanidegas), physical methods (flamethrower), housing improvement and community participation

1944-46 Still in Bambuí, beginning of chronic cardiopathy systematization; failure of DDT against triatomines; Dias warns against the risk of transfusion disease

1947-48 First laboratory trials against insects (Busvine \& Barnes 1947) and description of the action of $\mathrm{HCH}$ (gammexane) against triatomines (Dias \& Pellegrino, Romaña \& Abalos); first large scale survey employing serology and EKG in non-selected population (Bambuí)

1949 First regional serological survey of blood donors (Pellegrino, in Belo Horizonte, Brazil); L Dao confirms in Venezuela the congenital transmission of human Chagas disease; Ramos and Freitas carry on a serological and EKG inquiry in Cássia dos Coqueiros, SP, Brazil

1950-52 In São Paulo, Brazil, Nussensweig, Freitas and Amato Neto confirm transfusional transmitted Chagas disease. The same group employs successfully gentian violet as chemoprophylactic agent in blood banks. First large-scale trial with gammexane against triatomines in Uberaba, Minas Gerais, Brazil (E Dias, Bustamante et al.)

1955 First experimental trial attempting Triatoma infestans eradication in Bambuí (E Dias)

1956 Publication of the definitive systematization of chronic heart Chagas disease in Circulation by Laranja, Dias, Nóbrega and Miranda

1957-58 Re-description of Chagas disease digestive forms by Köberle and others. Important serological and EKG survey in the Córdoba region of Argentina, by Rosenbaum and Cerisola. Important regional epidemiological surveys in Venezuela, by Pifano et al.

1959 Neghme and Schenone confirm in Chile the results obtained in Bambuí against T. infestans. E Dias emphasises the concept of $T$. infestans eradication

1960-70 Beginning of vector control in São Paulo, Brazil, and in Venezuela (National Programme: using insecticide plus hous- 
ing improvement); regional actions in Argentina and in various Brazilian states; P Freitas introduces his concept of selective spraying. Improvement of new serological techniques for diagnosis (indirect immunofluorescence, direct agglutination and indirect haemagglutination); registration of low levels of resistance to organochlorine insecticides (dieldrin and BHC) in part of Venezuela, promptly resolved by changing the product to a carbamate compound (propoxur); first optimistic results of nifurtimox, against acute forms of human Chagas disease; improvement of chemoprophylaxis in blood banks of Argentina and Brazil, besides the increasing of prevalence surveys among blood donors in the entire Continent; still timid improvement of blood bank serological control is observed in endemic regions; the first positive serological results are registered in worked areas of Brazil (Bambuí, São Paulo), Venezuela (Belén, Eneal) and Argentina; beginning of the trials with new anti-arrhythmic drugs (amiodarone) for chronic cardiopathy

1970-80 Beginning of the national programme in Uruguay (1972); reformulation of the Brazilian programme in 1975 , based on E Dias' ideas concerning a systemic approach taking into account the continuity of the actions in contiguous areas; complete revision of transfusion transmitted Chagas disease by Cerisola et al. (Argentina); first community based surveillance against triatomines in Bambuí; beginning of the national entomological and serological surveys in Brazil; improvement of applied and basic research in Brazil supported by the Ministry of Health and Brazilian Research Council [Integrated Programme of Endemic Diseases (PIDE, followed some years later by TDR/UNDP-WB-WHO)]; first trials with benznidazole; Alma-Ata meeting, bringing the concept of Public Health activities based on the primary health care system; generalisation of the concept of the regional differences on Chagas disease morbidity; still a very slow advance in the coverage of blood banks with preventive serology and/or chemoprophylaxis; beginning of the annual meeting on basic research (Caxambu, Brazil); at the end of the decade, a book edited by Zigman Brener and Zilton Andrade as well as an International Congress on Chagas Disease (Rio de Janeiro), call the attention of authorities and scientific community to the disease and its control; in New York, publication of Lent and Wygodzinsky's compendium about triatomines; in Venezuela, Gomez-Nuñes develops a simple model of passive sensor to triatomines; spreading of the HAI and IIFT serological tests in endemic countries, slowly replacing the pioneer CFT; first trials of pyrethroid insecticides in Minas Gerais and Rio de Janeiro (Brazil) and in Argentina

1980-90 Aids emergence and dispersion, inducing the reformulation of haemotherapy throughout the world, so making compulsory the serological screening of blood donors; progressive replacement of ancient insecticides by modern pyrethroids; mathematical simmulations (J Rabinovich) show that vector control is feasible mainly when insecticide, housing improvement and social progress are associated; first regional programmes in Chile and Bolivia; political decision in Brazil, resulting in the allocation of resources to expand programme coverage to entire endemic area, without discontinuity; beginning of the annual meeting on applied research in Brazil (Araxá, then Uberaba) and some important periodical meetings in Argentina (Carlos Paz, La Falda, etc.); beginning of the "Programa de Salud Humana", headed by Dr Pilar Alderette in Argentina (BIRD/Universidad El Salvador), stimulating several emergent regional groups for the diagnosis and control of Chagas disease in Argentina, Uruguay, Chile, Brazil, Paraguay and Bolivia; the results obtained by the control programmes in São Paulo and other Brazilian parts call attention to vigilance strategies formerly developed in Bambuí; detailed studies of the population dynamics of Triatominae developed in Venezuela (Rabinovich), Brazil (Marsden, Schofield) and Argentina (Gorla) help to improve new control strategies; important publications in Brazil about the ecology of vectors and reservoirs (O Forattini \& M Barretto); a national electrocardiographic survey is carried out in Brazil, showing regional differences; financial constraints result in the decreasing of 
Venezuelan programme; development of the ELISA technique for serology; general improvement in the medical attention for acute and chronic patients, mainly at the level of cardiac arrythmias, cardiac failure and mega-syndrome diagnosis and surgery; important advances in cardiopathy studies with the generalisation of ecocardiographic, holter, exercise tests and other investigation procedures; generalisation of cardiac transplantation and pace-maker implantation; spreading of social and costbenefit studies about the disease and its control; introduction of Aedes aegypti and dengue fever in Brazil, resulting in relative disactivation of Chagas disease programme; the entomological results in Brazil Uruguay and Argentina make clear that elimination of $T$. infestans is an attainable goal, and that the surveillance strategy, peridomestic Triatominae and secondary species will constitute a challenge for the next decade; in some countries (Argentina, Brazil, Uruguay), a law about blood transfusion is implemented

1990-99 Preliminary studies at the scientific level and final resolution of the Ministries of Health of Argentina, Bolivia, Brazil, Chile, Paraguay and Uruguay implement the "Southern Cone Initiative for elimination of $T$. infestans and Control of Transfusion Transmitted Chagas Disease" (Brasília); progressive disactivation of PIDE and Chagas disease TDR research programmes; ECLAT research network launched with support from EC and Switzerland; improvements are made in chemoprophilaxys of stored blood banks in order to short the time of parasite disactivation (Moraes Souza); progressive disactivation of the conventional vertical programmes in Argentina, Brazil and Venezuela, because of the transition to horizontal peripheral systems and the new model of "modern and small central structures"; improvement of the research to new areas, such as Amazon Region and to other less well studied regions (Central America, México); Paraguay begins national programme in 1994; longitudinal, sectional and experimental studies show that treatment with benznidazole and/or nifurtimox can be effective in young and even adult patients, providing parasitological cure and even the interrup- tion of the progression of chronic lesions; other endemic countries implement blood bank control; results of vector control in Brazil and Uruguay show a positive impact on decreasing of transfusion and congenital transmitted Chagas infection, as well as on the morbidity and mortality patterns of the disease; new regional "initiatives" arise in Central America and Andean Regions; Mexico starts a regional pilot programme against domiciliated triatomines; the Global Conference on Disease Elimination (Atlanta, USA), considers Chagas disease as a clear candidate for elimination up to the year 2010; in 1999, Bolivia assumes an historical decision to implement a complete national control programme in all endemic areas, allocating external and national resources to guarantee its continuity over the next five years; at the same time, national control programmes start in Peru, Colombia and Central America (Honduras, El Salvador, Nicaragua and Guatemala, and a plan is made for Costa Rica); entomological studies carried out through the ECLAT net work show the possibility of Rhodnius prolixus elimination in Central America, since this species is out of its original dispersion centre

This very short and simple summary reveals to us a history involving men, research, social policies, political will and technological development. It must be emphasised that HCD never received a high social priority because of several and different factors such as the very weak socially involved population (poor, rural, isolated, non-organised, etc.) and the lacking of specific treatment for several years, of medical interest on the disease, of formal education involvement, of an effective policy considering agriculture and rural housing in endemic countries, and also the very weak market concerning the main trade tools involved in HCD: insecticides and laboratory reagents for diagnosis. It is very peculiar the fact of scientific community involvement in all this history, since Carlos Chagas, following his examples with a very clear social compromise, many times leaving the hospitals and laboratories to push on political decisions. In the history of Chagas disease control, was necessary more than research and epidemiological data to move on national and regional programmes. An additional work was required to sensitise the public opinion, to influence the national governments and to stimulate leadership formation and decision making (Morel 1998). 
THE PRESENT SITUATION OF CHAGAS DISEASE CONTROL IN ENDEMIC COUNTRIES

In a general way, the endemic countries can be considered according their epidemiological situation (vectors, transmission rate, prevalence and morbidity) and by the state of national control programmes. Serology of children and blood donors provides useful epidemiological information, as do electrocardiographical surveys of infected and non-infected individuals (Schmunis 1991, Dias \& Coura 1997). Unfortunately, representative and comparable data are not available in the majority of countries, chiefly those concerning morbidity. Chagas disease is not homogenously distributed in the endemic countries, but tends to be in microregional clusters that generally depend of the level of domestic colonisation by vector species. National and regional control programmes prioritise chemical control of vectors, together with screening of blood donors as the basic strategy to HAT control, supported by Health Education and community organisation. Chemoprophylaxis of transfused blood has not been implemented in recent years (WHO 1991, Dias 1997). In the Southern Cone, chronic heart disease is the bigger problem among infected people of the region, being present in more than $20 \%$ of them, while digestive "megas" affect up to $10 \%$. Acute cases usually disappear immediately when a locality is treated. At present, Argentina, Bolivia, Brazil, Chile, Paraguay and Uruguay are implementing programmes for the elimination of T. infestans, as the best way to reach the minimum level of disease transmission. Nevertheless, secondary triatomines such as T. sordida, T. pseudomaculata and P. megistus can invade dwellings (chiefly in Brazil) and must be faced throughout effective and continuous vigilance. The most advanced programmes are in Uruguay, Chile, Brazil and Argentina, where current levels of transmission are now low (see Tables III, V). In these countries, the control of blood banks is also being improved, with a high degree of coverage and very low prevalence of infected blood donors. Financial support of national programmes in these countries has been maintained in the last eight years, but the availability of trained personnel is declining, either because of the decentralisation policies or by the demand of other emergent problems, chiefly dengue fever. Progressive disactivation of traditional programme structures is leaving administrative gaps at regional and municipal levels, which generally are not prepared to assume the control activities and to maintain the consequent surveillance. In Bolivia, original centre of dispersion of T. infestans, the epidemiological indicators are high, with a mean rate of infection in blood donors of around $40 \%$ in endemic areas, and over
$5 \%$ in non endemic regions, while the only controlled blood bank is in Sta. Cruz City. Bolivia has launched a new national programme, with Presidential backing, and - for the first time - adequate financial resources (more than US\$ 30 million) to spray approximately 700,000 houses and to control all blood banks within the next five years. Paraguay has also an important level of transmission: in the Chaco Region the mean house infestation rate by $T$. infestans reaches more than $30 \%$, while the prevalence of infection is over $25 \%$ amongst pregnant women. The vector control programme still remains in a phase of organisation. Nevertheless, the control of blood banks and a national policy to detect and to treat congenital cases are rapidly being improved in the country. Peru has an important endemic area (Arequipa and Tacna regions), and is now developing a national programme for the elimination of T. infestans from the infested southern departments, and progressive control of blood banks. As a whole, the elimination of $T$. infestans is now considered an attainable goal, since this insect has no wild foci (except in limited areas of central Bolivia) and infestation rates decrease dramatically in all sprayed areas.

In the Andean Pact region (Ecuador, Colombia and Venezuela) the main vectors are $R$. prolixus, and $T$. dimidiata, with several other species of local importance. $R$. prolixus is the principal regional vector in Venezuela and Colombia, where it is highly domesticated. The principal disease impact is due to chronic cardiopathy, which affects about $20 \%$ of infected Venezuelan individuals, whereas, digestive chronic forms seem to be not observed in this region. Venezuela has implemented a large-scale programme of Chagas disease control, where during more than 20 years there was intensive house spraying and more than 600,000 rural houses were improved in endemic areas. Unfortunately, the national programme has weakened in the last decade, with progressive loss of human and financial resources, the complexities of decentralisation and the emergence of dengue. In 1997 however, following encouraging results in the Southern Cone, a new Andean Pact initiative was agreed. Colombia has quickly developed improved systems of blood bank control, and is now implementing a national programme to eliminate $R$. prolixus; Ecuador has begun vector control trials (especially in Guayaquil), and intensified vector control activities in Venezuela are expected.

The Central American initiative, also launched at the end of 1997, mainly involves Guatemala, Honduras, El Salvador and Nicaragua. In these countries, the most important vector is $R$. prolixus, which is considered a feasible candidate for eradi- 
cation from the region since it appears to be exclusively domestic. Moreover, genetic studies show that it was probably imported some 80 years ago from Venezuela, and now has an extremely limited genetic repertoire compared to the original Venezuelan and Colombian forms. $R$. prolixus is associated with very high rates of human infection (typically over $40 \%$ in Honduras and Guatemala) but it has a limited and focal distribution. In contrast, $T$. dimidiata is extremely widespread in Central America - even in periurban areas - but is generally associated with human infection rates of 8$12 \%$. T. dimidiata cannot be considered a candidate for eradication since it also has widespread sylvatic foci, so that its control will require the development of continuous community-based vigilance systems. The distribution of $T$. dimidiata extends from southern Mexico throughout Central America into Panama, Colombia, Ecuador and northern Peru. In Panama, the main vector of human Chagas disease is $R$. pallescens, with very low house colonisation. Although results from recent surveys have yet to be fully analysed, it seems that the highest prevalence rates are found in Guatemala, Honduras and Nicaragua, with a mean rate of infected blood donors between 4 and $8 \%$. Chronic Chagas heart disease seems less common and less severe compared to Southern Cone countries, and digestive forms are rare. But the morbidity and prevalence of HAT in Central American countries are more intense in those areas infested by $R$. prolixus, rather than those where $T$. dimidiata (or other species) dominate.

In Mexico, in spite of an excellent tradition of Chagas disease research in the 1950s and 1960s, the importance of Chagas disease was largely overlooked until the current decade. In 1992, a large scale serological survey of blood donors and rural populations indicated an overall infection prevalence of over 500,000 cases, and subsequent surveys have confirmed high levels of infection, especially in the southern and central states. Since 1997, an improved system of screening of blood donors has been progressively developed, although coverage remains incomplete. Vector control activities have yet to be implemented on a large scale, although the first trials using modern pyrethroids were begun in 1998. The main vectors are members of the T. protracta group of species (especially T. barberi) and members of the T. phyllosoma group (especially $T$. pallidipennis). All of these seem to have extensive sylvatic ecotopes as well as colonising peridomestic and domestic habitats, and are subject of major research efforts to clarify the most appropriate methods for control and surveillance.

Data on the remaining countries remains scarce. Amongst the caribbean islands, several report the presence of potential vectors - particularly $T$. maculata and $P$. geniculatus in islands close to the mainland, and members of the T. flavida group in Cuba and Jamaica - but there appears to be no active transmission of human Chagas disease on these islands. In the Guianas (Guyana, Suriname and French Guiana) several species of Rhodnius and Panstrongylus have been reported, occasionally entering houses, and a few acute cases of Chagas disease have been reported from parts of French Guiana. At present however, there are no national programmes for surveillance or control of the disease in these countries, either in terms of vector control or in monitoring of blood donors.

\section{RESEARCH NEEDS AND FINAL CONSIDERATIONS}

The most visible framework shows that research is still necessary either to solve some actual constraints or to prevent possible epidemiological changes in the future. First of all, the basic control strategies are available and can provide a good chance that HAT transmission can be substantially reduced within the next few years, in spite of some constraints existing at each control level. At the other side, about 16 million of yet infected individuals deserve medical attention, an important subject in which the researcher finds higher challenges than in primary control. To the next future a very low level of transmission is expected, a fact that claims for a better and long term sustained epidemiological surveillance. Secondary vector species and an effective management of peri-domestic ambient require more and more attention. Considering the different control levels, the more urgent research needs could be summarised as follows (Table IV).

Many accounts of Chagas disease present a dismal picture of incurable infection consigning millions to chronic debility, ignored by all but a handful of research workers and rural clinicians. But this picture has changed dramatically in recent years. Advances in diagnosis, and improvements in understanding and treating the infection, have led to much better disease management and increased awareness that chagasic individuals can generally fulfil an entirely normal role in society. Most importantly perhaps, there is now wide recognition that transmission of the parasite can be halted, with national, regional and international programmes designed to improve the screening of blood donors and implement effective control of the insect vectors. Today, over vast areas of the once endemic regions, acute cases of Chagas disease are no longer seen, and the risk of new infection (of all transmission routes) is diminishing rapidly as the control programmes achieve wider geographical coverage. And vector control has brought additional advantages to rural communities, 


\section{TABLE IV}

Research needs to Chagas disease control at present time, according to the different epidemiological levels

\begin{tabular}{lll}
\hline Control level & Required research & General comments \\
\hline Vector control & Better insecticide and methodology at the & Community participation and the \\
& peri-domestic level & maintenance of political will in \\
& Better triatomine trapping in low densities & very low bug densities will be a \\
& Better organisation of epidemiological & major challenge in the next future \\
& surveillance &
\end{tabular}
surveillance

Monitoring of sylvatic-domestic

triatomine migration

Monitoring of triatomine resistance to insecticides

Transfusion transmission $\quad$ More rapid, sensible and specific serology More rapid, effective and non toxic drug in chemoprophilaxis Institutional research about the quality of haemotherapy

Congenital Transmission

Accident and organ transplantation

Specific treatment

Symptomatic treatment

Programme organisation
Development of tools to detect precociously congenital transmission Immunoprophilaxis (still not available)

More efficient drugs to chemoprophilaxis Studies on risk factors

More effective and less toxic drugs

Cardiopathy: more efficient drugs and procedures to control arrythmias, heart failure and trombo-embolic syndrome; improvement of precocious diagnosis of cardiopathy and immune modulation of fibrosis (not available); digestive: improvement of farmacologic and surgical treatment of digestive lesions

How to improve the minimum continuity and quality, as well as the information flow in horizontal and decentralised operative structures? Analysis of causes, consequences and risk factors involving the failure and weakening of national and regional programmes
Cost-benefit relations worse in advanced phases of the programme, when the level of transmission is very low. In general, better indication and quality of hemotherapy are required, mainly in smaller towns

Better organisation and coverage on peripheral primary health care system are required

There is not adequate registration/ information

Indications for treatment are increasing to chronic cases

Precocious diagnosis and adequate medical and social attention remain the main challenge for human Chagas disease management

Improvement of regional reference centres concerning control, epidemiology, medical care, diagnosis, entomology, etc., is required whereby families can now sleep undisturbed, in even the poorest of dwellings, without the risk of attack by blood-sucking Triatominae. The dilemma remains in the same social and biological factors involved in HAT and very early detected by Carlos Chagas: poverty, and low political priority of affected populations, by one side, and a terrible chronic disease transmitted by the opportunistic insect, at the other.

In addition to the social and medical benefits of Chagas disease control, the financial benefits are also substantial. In planning the Southern Cone programme, it was estimated that an investment in Chagas disease control would produce an annual eco- nomic return equivalent to $14 \%$ in medical savings alone (Schofield \& Dias 1991). Since then, studies in Brazil have shown a real economic rate of return of over 30\% (Akhavan 1997) while studies in Argentina indicate rates of return in excess of $60 \%$ (Del Rey et al. 1995, Basombrio et al. 1998). For Brazil during the period 1983-1996, the analysis indicates a national expenditure on Chagas disease control of about $\$ 400$ million, producing savings of over $\$ 900$ million in terms of improved survivorship alone, preventing at least 277,000 new cases of infection and 85,000 deaths (Akhavan 1997).

The main challenge is to consolidate and extend these successes to implement control programmes 
TABLE V

General situation of Chagas disease and programme control in different countries or regions

\begin{tabular}{|c|c|c|c|c|c|c|}
\hline \multirow[t]{2}{*}{$\begin{array}{l}\text { Country/ } \\
\text { Region }\end{array}$} & \multicolumn{2}{|c|}{$\begin{array}{c}\text { Prevalence } \\
(\%)\end{array}$} & \multirow[t]{2}{*}{$\begin{array}{c}\text { Infestation } \\
(\%)\end{array}$} & \multirow[t]{2}{*}{$\begin{array}{c}\text { Main } \\
\text { vectors }\end{array}$} & \multirow[t]{2}{*}{$\begin{array}{l}\text { Blood } \\
\text { control }\end{array}$} & \multirow[t]{2}{*}{ Program/Observations } \\
\hline & (a) & (b) & & & & \\
\hline Argentina & 1.9 & 4.4 & $<5.0$ & $\begin{array}{l}\text { Triatoma } \\
\text { infestans }\end{array}$ & $>90.0$ & $\begin{array}{l}\text { Regular decentralised; lacking of human } \\
\text { resources (HR) }\end{array}$ \\
\hline Bolivia & $>30.0$ & $5-55.0$ & $>20.0$ & T. infestans & $<5.0$ & Starting 1999; decentralised \\
\hline Brazil & 0.17 & $<0.8$ & $<3.0$ & $\begin{array}{l}\text { P. megistus/ } \\
\text { T. brasiliensis }\end{array}$ & $>80.0$ & $\begin{array}{l}\text { Regular; vertical>decentralised; more than } \\
90 \% \text { in surveillance }\end{array}$ \\
\hline Chile & 1.1 & 0.9 & $<1.0$ & T. infestans & $>90.0$ & Regular decentralised; mainly surveillance \\
\hline Paraguay & 5.0 & 5.7 & $>5.0$ & T. infestans & $\sim 30.0$ & Starting 1999; decentralised; HR \\
\hline Peru & NA & 0.4 & NA & T. infestans & $<20.0$ & Starting in Arequipa region 1999 \\
\hline Uruguay & $<1.0$ & 0.62 & $<1.0$ & T. infestans & 100.0 & Regular-decentralised; only surveillance; HR \\
\hline Colombia & NA & 1.2 & NA & $R$. prolixus & NA & Starting regular programme \\
\hline Ecuador & NA & 0.2 & NA & T. dimidiata & NA & No regular programme; planning (1999) \\
\hline Venezuela & $<3.0$ & 0.7 & NA & $\begin{array}{l}\text { R. prolixus/ } \\
\text { T. maculata }\end{array}$ & $>70.0$ & $\begin{array}{l}\text { Regular semi-disactivated programme } \\
\text { (vertical>decentralised); HR }\end{array}$ \\
\hline Guyanes & $<1.0$ & NA & NA & $?$ & NA & No programmes \\
\hline Panamá & NA & $<3.0$ & NA & R. pallescens & NA & No programme \\
\hline C. Rica & NA & 2.5 & NA & T. dimidiata & NA & No programme. \\
\hline Nicaragua & NA & $<1.0$ & NA & T. dimidiata & NA & Planning (1999) \\
\hline Honduras & NA & 1.2 & $>10.0$ & $\begin{array}{l}\text { T. dimidiatal } \\
\text { R. prolixus }\end{array}$ & $<50.0$ & Starting regular actions (1998-1999) \\
\hline Guatemala & NA & $>5.0$ & $>10.0$ & $\begin{array}{l}\text { T. dimidiatal } \\
R \text {. prolixus }\end{array}$ & $<50.0$ & Starting regular actions (1999) \\
\hline E Salvador & NA & 1.9 & NA & $\begin{array}{l}\text { T. dimidiatal } \\
R \text {. prolixus }\end{array}$ & NA & No programme \\
\hline Belize & NA & $<2.0$ & NA & T. dimidiata & NA & No programme \\
\hline Mexico & NA & $<5.0$ & NA & $\begin{array}{l}\text { T. pallidipennis/ } \\
\text { T. longipennis }\end{array}$ & $<20.0$ & No programme; pilot trials beginning (1998) \\
\hline USA & NA & $<0.05$ & $<0.005$ & T. protracta & $<5.0$ & No programme; blood control to Latin American \\
\hline Caribe & NA & $<0.1$ & NA & $?$ & NA & No programmes \\
\hline
\end{tabular}

(a): children (\%); (b): blood donnors (\%); NA: not available.

in countries where Chagas disease exists but is not fully confronted, and to maintain those programmes that have already been launched. In the first case, political priority must be assumed and reinforced by consistent epidemiological data. For existing programmes, as in Brazil, the priority is to maintain the political momentum in order to extend programme coverage. And this is by no means a simple task within the extensive policies of decentralisation, which are now being implemented in Brazil and elsewhere. The basic problems, here, concern with two different situations: (a) how to maintain efficiency and effectiveness at peripheral levels which many times are not ready to assume this kind of work, and, (b) how to assure epidemiological and social priorities, at those levels, where personal and political interests use to be the main determinants of actions. We have reached the stage where effective disease control is less of a technical problem, but rests more and more in the domain of administration and organisation.

\section{REFERENCES}

Akhavan D 1996. Análise de custo-efetividade do programa de controle da doença de Chagas no Brasil. Monographic paper. Brasília. National Health Foundation (Ministry of Health), $44 \mathrm{pp}$.

Andrade SG 1999. Terapêutica experimental. Work presented in the round table "Chagas disease". XXXV Brazilian Congress of Tropical Medicine, Guarapari, ES, Brazil.

Basombrio MA, Del Rey EC, Rojas EC, Schofield CJ 1998. A cost-benefit analysis of Chagas disease control in Northwest Argentina. Trans R Soc Trop Med Hyg (in press).

Brener Z 1987. Laboratory-acquired Chagas disease: comment. Trans R Soc Trop Med Hyg 81: 527.

Busvine JR, Barnes S 1947. Observations on mortality among insects exposed to dry insecticidal films. Bull Entomol Res 38: 80-81.

Briceño-León R 1993. La enfermedad de Chagas: una construcción social, p. 257-282. In R Briceño-León \& JCP Dias (eds), Las Enferme-dades Tropicales en la Sociedad Contemporanea, Acta Científica de Ven- 
ezuela, Caracas.

Caldas Jr AL 1980. Epidemiologia e Controle da Doença de Chagas: Relação com a Estrutura Agrária na Região de Sorocaba, SP, MSc Thesis, Faculdade de Medicina, Universidade de São Paulo, São Paulo, $102 \mathrm{pp}$.

Chagas CRJ 1911. Segunda conferência realizada na Academia Nacional de Medicina, em agosto de 1911, p. 167-192. In AR Prata Carlos Chagas: Coletânea de Trabalhos Científicos, Universidade de Brasília, Brasília.

Chagas CRJ 1926. Aula inaugural do Prof. Carlos Chagas da Cadeira de Medicina Tropical, p. 137-166. In Chagas CRJ 1935. Discursos e Conferências, Rio de Janeiro.

Chagas CRJ 1934. Estado actual da trypanosomiase americana. Comunicação feita à Semana do Laboratório, São Paulo, janeiro de 1932. Rev Biol Hig S Paulo 5: 58-64.

Coura JR 1997. Síntese histórica e evolução dos conhecimentos sobre a doença de Chagas, p. 469486. In JCP Dias \& JR Coura (eds) Clínica $e$ Terapêutica da Doença de Chagas. Um Manual Prático para o Clínico Geral, Editora Fiocruz, Rio de Janeiro.

Del Rey EC, Basombrio MA, Rojas CL 1995. Beneficios brutos de la prevención del mal de Chagas. Castañares 3 (cuaderno 4) $75 \mathrm{pp}$.

Dias E 1944. Um Ensaio de Profilaxia na Moléstia de Chagas, Imprensa Oficial, Rio de Janeiro, 89 pp.

Dias E 1957. Profilaxia da doença de Chagas. O Hospital 51: 285-298.

Dias E, Pellegrino J 1948. Alguns ensaios com o "Gammexane" no combate aos transmissores da doença de Chagas. Brasil-Méd 62: 185-191.

Dias JCP 1978. Doença de Chagas, p. 53-76. In R Guimarães, Saúde e Medicina no Brasil, Graal, Rio de Janeiro.

Dias JCP 1987. Control of Chagas disease in Brazil. Parasitol Today 3: 336-341.

Dias JCP 1988. Reseña histórica de los conocimientos sobre la enfermedad de Chagas y reflexiones sobre algunos aspectos políticos y socio-económicos de la endemia en el contexto latinoamericano. Rev Fed Argentina Cardiol 17: 121-135.

Dias JCP 1990. Doença de Chagas: Clínica $e$ Terapêutica, Ministério da Saúde (Sucam), Brasília, $76 \mathrm{pp}$.

Dias JCP 1991. Chagas disease control in Brazil: which strategy after the attack phase ? Ann Soc Bélg Med Trop 71 (Suppl.1): 75-86.

Dias JCP 1993. Situación actual de la enfermedad de Chagas en las Américas, p. 1-12. In RJ Madoery, C Madoery \& M Cámera (eds) Actualizaciones en Enfermedad de Chagas. Congreso Nacional de Medicina, Córdoba.

Dias JCP 1993a. Vigilância epidemiológica contra Triatoma infestans. Rev Soc Bras Med Trop 26 (Supl. 3): 39-44.

Dias JCP 1993b. Cinquenta anos de Bambuí. Rev Soc Bras Med Trop 26 (Supl. II): 4-8.

Dias JCP 1994. Ecological aspects of the vectorial con- trol of Chagas disease in Brazil. Cad Saúde Púb 10 (Supl. 2): 352-358.

Dias JCP 1997. Controle da doença de Chagas, p. 453468. In JCP Dias \& JR Coura (eds) Clínica e Terapêutica da Doença de Chagas. Um Manual Prático para o Clínico Geral, Fiocruz, Rio de Janeiro.

Dias JCP, Brener Z, Macedo MAM 1986. Quimioprofilaxia da doença de Chagas induzida por transplante renal com doador infectado. Rev Bras Med 43: 39-43.

Dias JCP, Coura JR 1997. Epidemiologia, p. 33-66. In JCP Dias \& JR Coura (eds) Clínica e Terapêutica da Doença de Chagas. Um Manual Prático para o Clínico Geral, Fiocruz, Rio de Janeiro.

Dias JCP, Schofield CJ 1998. Controle da transmissão transfusional da doença de Chagas na iniciativa do Cone Sul. Rev Soc Bras Med Trop 31: 373-383.

Ferreira MS, Nishioka SA, Rocha A, Silva AM 1997. Doença de Chagas e imunossupressão, p. 365-382. In JCP Dias \& JR Coura (eds) Clínica e Terapêutica da Doença de Chagas. Um Manual Prático para o Clínico Geral, Fiocruz, Rio de Janeiro.

Freitas JLP 1963. Importância do expurgo seletivo dos domicílios e anexos para a profilaxia da moléstia de Chagas pelo combate aos triatomíneos. Arq Hig (S. Paulo) 28: 217-272.

Garcia Zapata MT, Schofield CJ, Marsden PD 1985. A simple method for detecting the presence of live triatomine bugs in houses sprayed with insecticides. Trans R Soc Trop Med Hyg 79: 558-559.

Gomes-Nuñes JC 1965. Desarrollo de un nuevo método para evaluar la infestación intradomiciliaria por Rhodnius prolixus. Ac Cientif Venez 16: 26-31.

Gurtler RE, Schweigmann NJ, Cecere MC Chuit R Wisnivesky-Colli C 1993. Comparison of two sampling methods for domestic populations of Triatoma infestans in north-west Argentina. Med \& Veter Entomol 7: 238-242.

Hayes R, Schofield CJ 1990. Estimación de las tasas de incidencia de infecciones y parasitosis crónicas a partir de la prevalencia: la enfermedad de Chagas en America Latina. Bol Ofic Sanit Panam 108: 308316.

Kingman S 1991. South America declares war on Chagas disease, p. 16-17. New Scientist (19 October 1991).

Laranja FS 1949. Evolução dos conhecimentos sobre a cardiopatia da doença de Chagas. Revisão crítica da literatura. Mem Inst Oswaldo Cruz 47: 605-669.

Laranja FS, Dias E, Nóbrega GC, Miranda A 1956. Chagas disease. A clinical, epidemiologic and pathologic study. Circulation 14: 1035-1160.

Litvoc J 1985. Doença de Chagas e Estrutura Social: Infestação Domiciliar e Infecção Humana em Áreas Submetidas a Ações de Controle, Thesis, Faculdade de Medicina, Universidade de São Paulo, São Paulo, $118 \mathrm{pp}$.

Moraes De Souza H, Ramirez LE, Bordin LO, 1997. Doença de Chagas transfusional: medidas de controle, p. 429-444. In JCP Dias \& JR Coura (eds), Clínica e Terapêutica da Doença de Chagas. Um Manual Prático para o Clínico Geral, Fiocruz, Rio de Janeiro. 
Morel CM 1998. Chagas disease from discovery to control. History, myths and lessons to take home. WHO/ RPS/ACHR35, Geneva, $30 \mathrm{pp}$.

Oliveira Filho AM 1989. Cost-effectiveness analysis in Chagas disease vector control interventions. $\mathrm{Mem}$ Inst Oswaldo Cruz 84 (Suppl. IV): 409-417.

PAHO 1993. Iniciativa del Cono Sur. PAHO document number PNSP/92-18.rev.1. Pan American Health Organization, Washington, $36 \mathrm{pp}$.

Rabinovich JE, Leal JA, Feliciangeli DP 1979. Domiciliary biting frequency and blood ingestion of the Chagas disease vector Rhodnius prolixus Stahl (Hemiptera, Reduviidae) in Venezuela. Trans $R$ Soc Trop Med Hyg 73: 272-283.

Rocha e Silva EO 1979. Profilaxia, p. 425-449. In Z Brener \& Z Andrade (eds) Trypanosoma cruzi e Doença de Chagas, Guanabara Koogan, Rio de Janeiro.

Romana C, Abalos JW 1948. Acción del "Gammexane" sobre los triatomideos. Control domiciliario. An Instit Med Reg Tucuman 2: 95-106.

Schmunis GA 1991. Trypanosoma cruzi, the etiologic agent of Chagas disease: status in the blood supply in endemic and non-endemic countries. Transfusion 31: 547-557.

Schmunis GA 1997. Tripanossomíase americana: seu impacto nas Américas e perspectivas de eliminação, p. 11-24. In JCP Dias \& JR Coura (eds) Clínica e Terapêutica da Doença de Chagas. Um Manual Prático para o Clínico Geral, Fiocruz, Rio de Janeiro.

Schmunis GA Zicker F, Moncayo A 1996. Interruption of Chagas disease transmission through vector elimination. The Lancet 348: 1171.

Schofield CJ 1978. A comparison of sampling techniques for domestic populations of Triatominae. Trans $R$ Soc Trop Med Hyg 72: 449-455.

Schofield CJ 1981. Chagas disease, triatomine bugs, and blood-loss. The Lancet $i$ : 1316.
Schofield CJ 1988. Biosystematics of the Triatominae, p. 284-312. In MW Service, Biosystematics of Haematophagous Insects Systematics Association, Special Vol. 37, Clarendon Press, Oxford.

Schofield CJ 1994. Triatominae: Biologia y Control. Eurocommunica Publications, W Sussex, 80 pp.

Schofield CJ, Dias JCP 1991. A cost-benefit analysis of Chagas disease control. Mem Inst Oswaldo Cruz 86: 285-295.

Schofield CJ, Dias JCP 1999. The Southern Cone programme against Chagas disease. Adv Parasitol 42: $1-25$.

Schofield CJ, Dujardin JP 1997. Chagas disease vector control in Central America. Parasitol Today 13: 141144.

Schofield CJ, Briceño-León R, Kolstrup N, Webb DJT, White GB 1990. The role of house design in limiting vector-borne disease, p. 187-212. In CF Curtis Appropriate Technology for Vector Control, CRC Press, Boca Raton, Fl.

Souza Araujo HC 1919. Doença de Chagas, p. 305-09. In HC Souza Araujo, A Prophylaxia Rural no Estado do Paraná: Esboço de Geografia Médica. Curitiba.

Szumlewiecs AP 1953. Ciclo evolutivo do Triatoma infestans em condições de laboratório. Rev Bras Malariol D Trop 5: 35-47.

Viotti R, Vigliano C, Lococo B, Armenti A 1997. Evolución de la miocardiopatía chagásica con y sin tratamiento etiológico. Medicina (Buenos Aires) 57 (Supl. III): 12-13.

Wendel S, Brener Z, Camargo ME Rassi A 1992. Chagas Disease (American Trypanosomiasis): its Impact on Transfusion and Clinical Medicine, ISBT, São Paulo, $271 \mathrm{pp}$.

WHO 1991. Control of Chagas Disease. Report of a WHO Expert Committee, WHO Technical Report Series no. 811, Geneva, 95 pp.

WHO 1997. Chagas disease. Interruption of transmission. Weekly Epidemiol Rec 72: 1-5. 